Babecka J. ${ }^{1}$, Lacko A. ${ }^{2}$

\title{
Proper adherence to pharmacotherapy in the elderly
}

\author{
${ }^{1,2}$ Catholic University in Ružomberok, Faculty of Health, Ružomberok, Slovakia \\ ${ }^{2}$ Central Military Hospital in Ružomberok, Department of Nuclear Medicine, Ružomberok, Slovakia
}

jozef.babecka@hotmail.com

\section{Introduction}

Aging is most often understood as the sum of structural and functional changes organism, which are manifested by increased vulnerability and decreased performance of the individual. The aging process is the effect on the body over time, basically aging since birth. These changes occur at an individual rate and at different times throughout the life of the individual. One person is changing very quickly, another is slower. The speed of aging is genetically encoded and at the same time influenced by lifestyle, environment, the work you do throughout your life, stress, and many other factors.

In theory, the maximum length of a persons life is about 115-120 years, but in practice it is extraordinary phenomenon. Old age is understood as the final stage of the aging process. This is the period for the end of each individual's natural development process. It is also known as the third period age, the first age being childhood and adolescence and the second age adulthood.

Periodization of old age. According to the World Health Organization (WHO) old age is divided into three periods: 60-74 years - early old age, 75-89 - old age itself, 90 years or more - longevity. In terms of age, we distinguish calendar age, which is the basic characteristic of man [1]. Its advantage is clarity, but it says nothing about the real functional potential of man.

The kinetics and dynamics of drugs during aging are dealt with in geriatric pharmacology. The field also addresses the adverse effects of drugs and their mutual interactions. Furthermore, it prepares the basis for rational pharmacotherapy of geriatric patients [2]. New drugs have not been previously tested in the elderly, and therefore, the knowledge of geriatric pharmacology is often obtained on the basis of the prior experience or meta-analysis of publications published after drug introduction into clinical trials practice.

Pharmacotherapy in old age is most influenced by age and disease related changes in the body. Aging itself is a physiological process that is relatively slow to the age of 60 , then accelerates over 10 years and slows down again after 70 years [3]. Physiological changes in the aging process include a decrease in cardiac output, a decrease left ventricular compliance, increased risk of arrhythmias, increased production catecholamines, the vital capacity of the lungs decreases, premature closure of small airways may occur in respiratory tract, losing muscle mass, strength and stamina, cartilage loses elasticity, decrease in the bone mineral content and osteoporosis, weakening of the immune system, the blood flow through the kidneys decreases, the number of glomeruli decreases, the water content of the organism decreases, production of hydrochloric acid, gastric and pancreatic juice is reduced, decreasing size of liver, there are changes in the visual and auditory apparatus, changes in the CNS [4]. In old age, sensitivity to certain types of medicines such as opioids and benzodiazepines decreases. When using drugs by people in older age you have to consider all these facts.

The effect of adverse factors on the individual results in pathological aging. In this the most common factor is a disease. Nowadays, with increasing years rises occurrence of cardiovascular diseases, tumors, neurological and lung diseases, metabolic diseases such as diabetes, the incidence of gastrointestinal tract diseases continues to increase and musculoskeletal system diseases. Due to this fact, the demands for specific pharmacotherapy is increasing and its related problems. The biggest problem is old age multimorbidity, which has a negative effect on the elimination of drugs, the occurrence of adverse effects; and their recognition.

Pharmacokinetics deals with the so-called fate of the substance in the body. There are changes in pharmacokinetics in old age. Firstly, it is the absorption of the substance from the site of administration, and then its distribution in the body and elimination, in which biotransformation and excretion processes are involved. These processes depend on the physical and chemical properties of the substance used and on the participating structures of the organism involved.

Drug absorption - low saliva production in seniors often results in reduced absorption of substances from the oral cavity. The use of proton pump inhibitors leads to an increase in $\mathrm{pH}$ in gastric stomach, which may affect the disintegration of orally administered dosage forms, ionizing the drug being released. By skowing gastric emptying in old age, there is a slowdown in the passage of substances from the environment with a small absorption area, to places with much larger area. If intestinal motility is also slowed, it will affect absorption in the lower parts of the digestive system. Absorption is also slowed down by decreased blood flow through the mesenteric region. Therefore, if it is a quick treatment, it is advisable to choose parenteral route of administration that provides immediate effect [5]. Skin absorption is also reduced due to the poor blood flow. This also applies to the subcutaneous tissue and muscles. 
Drug distribution. By reducing the fat-free mass, it also decreases distribution space for substances that dissolve in water, which is shown e.g. by reducing the initial dose of digoxin by $15 \%$. In old age, however, the amount of fat mass is increasing, resulting in an increase in the distribution space for the fat-soluble substances. Distribution of drugs depends on the permeability of some barriers and on the blood flow in individual tissues.In the elderly, the blood-brain barrier permeability is increased, which means for example more penetration of benzodiazepine into the brain. Many of the substances with neutral or acidic $\mathrm{pH}$ in plasma are bound to albumin. With the onset of old age, however, concentration albumin decreases. Warfarin binds the strongest to albumin.

Drug elimination occurs mainly in the kidneys. However, the number of nephrons decreases by about $0.5-1 \%$ every year. From 30-40 years of age the glomerular filtration rate decreases approximately o $8 \mathrm{ml} / \mathrm{min} / 1.72 \mathrm{~m}^{2}$ per decade. Due to the reduction of skeletal muscle, production of creatinine is reduced, thus a 85 -year-old man weighing $70 \mathrm{~kg}$ has the same creatinine concentration and has about half the glomerular filtration rate of a 20 -year-old male of the same weight [6].

Pharmacodynamics is concerned with monitoring the effect of the drug on the body. Changes in pharmacodynamics are caused by changes at the receptor level and changes in old age organism homeostasis. There may be lower or higher number of receptors, changes in conduction signal or a change in the final cell response. Structural changes in organs and tissues also play an important role. Less endorphine is produced in the brain of the elderly, which results in more free receptors, making the brain more sensitive to opioids. The older organism is also more sensitive to the administration of benzodiazepines. In addition, delirium may develop in patients with dementia when medicines with anticholinergic effects are administered, as acetylcholine production in the brain of seniors decreases. The fact that aging takes place individually creates large differences between elderly patients.

The manifestations of adverse drug reactions are an important prerequisite for rapid intervention of health professionals. Some side effects are manifested by non specific symptoms or changes in biochemical, haematological or physical tests. Even in normally used drugs, including benzodiazepines, hypnotics, and neuroleptics, severe side effects such as sedation, falls and confusion may occur. Nonsteroid anti-rheumatic drugsmay be responsible forbleeding into the GIT and confusion. Anticholinergics and spasmolytics may cause delirium or impair functional status. Instability and crashes arecaused by blood pressure lowering drugs. A complex of negative effects are also noted the effect of diuretics in the treatment of very elderly people with arterial hypertension. Effects such as falls, dehydration, homeostasis disorders, hyponatraemia and instability have occurred.

Geriatric patients with increased risk of adverse reactions: women withsmall height, patients with malnutrition, patients with less muscle mass, patients withdehydration, patients taking multiple medicines, patients with kidney and liver disease, patients with cognitive disorders.

\section{Prescription of drugs in seniors - possible risks:}

Excessive use of drugs - "Overuse" of medicines. This includes an unauthorized indication drugs, prescription and use of drugs in high doses, and we also includepolypragmase, i.e. irrational combination of multiple drugs in one patient. Reduced use - "under-use" of medicines. The product is either not administered at all or is administered in low doses where it does not have the effect it should have.Inappropriate prescription of medicines: when a geriatric patient is taking medicines that are potentially riskyin old age.

Patient's compliance means an effort to follow the doctor's instructions. These are mainly taking the right medicine and the right number of tablets, but also the right time when the medicine is must be taken. Because manual skills can be limited in geriatric patients, impaired vision or cognitive deficit, this often leads to problems with drug use [7]. This is especially true when the patient has to split the tablet, read it read the package leaflet, use a nasal spray or eye drops or open the cap with safety closures for children. It is proven, that the higher the number of ordinated drugs reduces compliance in elderly patients. However, we often encounter non-compliance of the therapeutic regime, when we talk about non-compliance.

\section{Conclusions}

Finally, we can ask the question "how to improve patient compliance"? We recommend to design the simplest and safest therapeutic regime, to educate the patient and family members about the importance of taking medication, to determine if the patient is able to take the medication andto treat it properly or if it is not, it must be taught, if it is not possible for the patient to learn how to handle the medicine properly, another person must supervise the use of the medicine, teach the patient to use medication, show him the dosing aids, avoiding prescription of half tablets and not to prescribe large tablets to patients with dysphagic problems.

\section{References}

1. Krajčík, Š. 2014. Notes on Ethics of Health Care for Seniors. In: Geriatria, Bratislava: Slovak Gerontological and Geriatric Society, 2014, No. 1/2014, ISSN 1335-1850.

2. Dúbrava, M. 2016. Health care quality indicators in geriatrics. In: Geriatria, Bratislava: Slovak Gerontological and Geriatric Society, 2016, č. 2/2016, ISSN 1335-1850.

3. Eybl V., Černá P. 2008 Basics of geriatric pharmacology, First Edition, Prague, Charles University, Prague, 2008, 107 p.

4. Hauke, M. 2014. Coping with problematic situations with seniors not only in care services. Prague: Grada, 2014, 128 p., ISBN 978-80-247-5216-7. 
5. Popovičová, M., Barkasi, D. 2018. The process of resolving conflict situations during provision of nursing care. In: Health sheets - scientific peer-reviewed magazine. volume 6, number 1. 2018. p. A8. ISSN 1339-3022.

6. Belovičová M., 2019. Selected Chapters from Geriatrics. Textbook for students of medical disciplines. University of Health and Social Work St. Elisabeth, Printer Svidnícka, 2019. 78 p. (4.5 AH), ISBN 978-80-8132-203-7.

7. Vansač, P., Education as a tool for quality of life of seniors, In: Dudek, M., Krukowski, J., Panas K., Senior Citizenship, Wydawnictwo Wyższej Szkoła Menedżerskiej w Warszawie im. Prof. Leszka J. Krzyżanowskiego, Warszawa 2014, p. 357-366, ISBN: 978-83-7520-176-5.

Дата надходження рукопису до редакції: 10.08 .2020 р.

Authors deal with seniors and their efforts to follow the instructions of health care professionals in drug use. The kinetics and dynamics of drugs during an individual's aging is a subject of study in geriatric pharmacology. This field also addresses the adverse effects of drugs and the interactions. Pharmacotherapy in old age is mostly influenced by old age and illness changes in organism. Aging is itself a physiological process that before age 60 proceeds relatively slowly, then it accelerates over 10 years and after 70 years again slows. Changes in pharmacodynamics in old age are due to changes in the receptor levels andchanges in homeostasis of the organism. There may be a lower or higher number of receptors, a change in signal conduction or change in the final cell response.

Key words: senior, pharmacotherapy, absorption of drugs, elderly.

Автори мають справу із людьми похилого віку та їхніми зусиллями виконувати вказівки медичних працівників щодо вживання ліків. Кінетика та динаміка лікарських засобів під час старіння людини є предметом вивчення в геріатричній фармакології. Це поле також розглядає шкідливі ефекти наркотиків та їх взаємодії. На фармакотерапію в літньому віці в основному впливають літній вік та зміни в організмі. Старіння саме по собі $є$ фізіологічним процесом, який до 60 років протікає відносно повільно, потім прискорюється протягом 10 років, а через 70 років знову сповільнюється. Зміни у фармакодинаміці в літньому віці зумовлені зміною рівня рецепторів та змінами гомеостазу організму. Може бути менша або більша кількість рецепторів, зміна провідності сигналу або зміна кінцевої реакції клітини.

Ключові слова: фармакотерапія, всмоктування ліків, люди похилого віку.

Авторы имеют дело с пожилыми людьми и их усилиями следовать инструкциям специалистов здравоохранения при употреблении лекарств. Кинетика и динамика лекарств в процессе старения человека являются предметом изучения гериатрической фармакологии. В этой области также рассматриваются побочные эффекты лекарств и их взаимодействия. На фармакотерапию в пожилом возрасте больше всего влияют изменения в организме в старости и болезни. Старение - это сам по себе физиологический процесс, который до 60 лет протекает относительно медленно, затем он ускоряется в течение 10 лет и снова замедляется после 70 лет. Изменения фармакодинамики в пожилом возрасте обусловлены изменением уровня рецепторов и изменением гомеостаза организма. Может быть меньшее или большее количество рецепторов, изменение проводимости сигнала или изменение окончательного ответа клетки.

Ключевые слова: фармакотерапия, абсорбция лекарств, пожилые люди.

Конфлікт інтересів: відсутній.

Conflicts of interest: authors have no conflicts of interest to declare.

\section{Автор для листування}

PhDr. PhD. Babecka Jozef - Catholic University in Ružomberok, Faculty of Health, Ružomberok, Slovakia. jozef.babecka@hotmail.com. 